This draft may differ slightly from the final version. Please cite the published chapter: Michnowicz, Jim. In press. "Maya-Spanish contact in Yucatan, Mexico: Context and sociolinguistic implications". To appear in S. Sessarego and M. González Rivera (Eds.). New Perspectives on Hispanic Contact Linguistics in the Americas. Madrid: Iberoamericana/Vervuert.

\title{
Maya-Spanish Contact in YuCATan, MeXico: ConteXt and SOCIOLINGUISTIC IMPLICATIONS
}

\author{
Jim Michnowicz \\ North Carolina State University
}

\section{Introduction}

Throughout the southern Mexican states of Yucatan, Campeche and Quintana Roo, as well as in northern Belize, Spanish is in contact with an indigenous language, Yucatec Maya (Lewis 2009). Yucatec Maya is part of a larger family of Maya languages that stretches from the Central American countries of Honduras and Guatemala in the south, to Tabasco on the Gulf of Mexico in the north, and is the second largest Maya language, after K'iche', spoken in the highland region of Guatemala (Lewis 2009). As of 2005 (the last date for which these data is available), the Mexican census reported 752, 316 Yucatec Maya speakers across the Yucatan peninsula, with a majority in the state of Yucatan $(527,107)$, and lesser, but still substantial amounts, in Campeche $(69,249)$ and Quintana Roo $(155,960)$ (INEGI 2005).

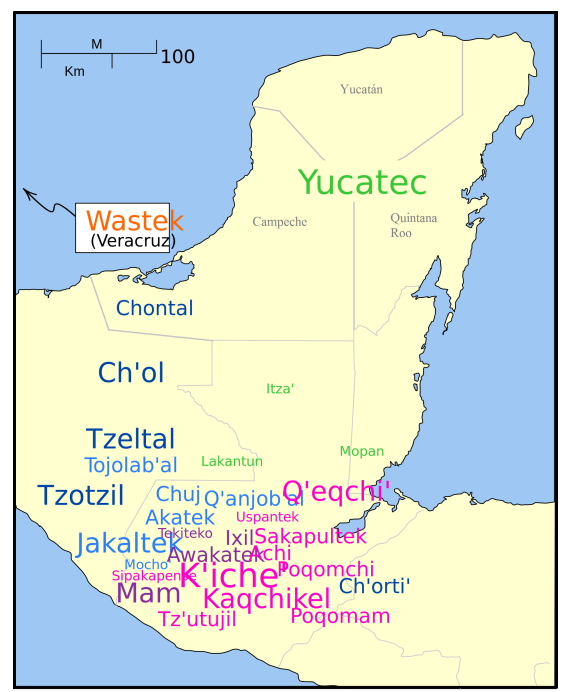

Figure 1. Map showing the distribution of Maya languages. Font size reflects the number of speakers. Modified under the GNU Free Documentation License from source: http://commons.wikimedia.org/wiki/File:Mayan_Language_Map.svg

This chapter will focus on the largest group of Yucatec Maya ${ }^{1}$ speakers in Yucatan state. First, I will contextualize the current situation of language contact by examining the historical background and demographics of Maya and Spanish speakers in Yucatan. I will then present the possible linguistic consequences of Maya-Spanish contact, synthesizing data from studies on phonetics/phonology, morphosyntax and the lexicon. Finally, I will address the future of Maya-Spanish contact in Yucatan, outlining

\footnotetext{
${ }^{1}$ Since "Maya" is the term used by native speakers of the language and for simplicity, this term will be used throughout the chapter.
} 
both efforts to revitalize the Maya language and the overall standardization of (possibly) Maya-influenced Spanish.

\section{Historical background and context}

According to historical records, Maya and Spanish first came into contact around 1511, when survivors of a Spanish shipwreck washed ashore in the southern Yucatan peninsula. Several short expeditions were made in the following decades, until 1527, when Francisco de Montejo, known as "El Adelantado", landed at Cozumel to undertake the conquest of Yucatan for the Spanish Crown. This first attempt at conquest failed, and one year later the Spanish abandoned Yucatan to regroup. Montejo, accompanied by his son (also Francisco de Montejo, known as "El Mozo"), returned around 1530, and again was forced to temporarily suspend military actions due to Maya resistance, the climate, and lack of supplies (Quezada 2001: 34). It was not until a decade later, in 1542, that Montejo the Younger founded the city of Merida on the site of the Maya city Tiho. The following year, in 1543, yet another Francisco de Montejo ("The Nephew") founded Valladolid in eastern Yucatan. Still, the conquest would not be considered complete until 1687, 160 years after it began (see Quezada 2001 for a more detailed overview of the conquest).

The result of this extended conquest and the difficulties the Spanish faced in colonizing Yucatan was that Spanish speakers were by and large isolated in the main Spanish cities of Campeche, Merida and Valladolid, with the countryside dominated by Maya speakers (Mosely 1980: 86; Lipski 2004: 99). Generally speaking, Yucatan (which in the colonial period referred to the modern states of Campeche, Yucatan and Quintana Roo) received less outside immigration than the rest of Mexico, with lower numbers of colonists from Europe and slaves from Africa than many other areas (Weber 1980: 173), and Spanish speakers comprised a very small percentage of the total population. In 1580, for example, the population of Yucatan was comprised of approximately 2000 Spaniards and 300 Africans, compared with 200,000 Maya. In 1700, the Spanish population had risen to 20,000 people, while the Maya population remained much higher, at 182,000 . Later in that century, the Spanish population rose dramatically to 103,000 , while the Maya population also rebounded to its highest level since the conquest $(254,000$ people) (Mosely 1980: 102-104). Even well into the 20th century, Maya speakers made up almost half of the population of Yucatan state, as seen in Figure 2. The isolation that separated Maya speakers in rural areas and Spanish speakers in urban areas during the colonial period has diminished over the past century, and the demographic situation in present day Yucatan is such that Spanish speakers are in constant contact with both Maya and Maya-influenced Spanish (Lipski 2004: 99). This became especially true in the latter half of the 20th century, as increasing numbers of Maya speakers have moved to cities looking for work as manual laborers, vendors, domestic help, and as nannies for Spanish-speaking families (Michnowicz 2009, 2011; Lipski 2004: 99). Thus contact between Maya and Spanish is of two different types: the first-hand contact that occurs among Maya-Spanish bilinguals, and the second-hand contact that brings Spanish monolinguals into contact with a Maya influenced, L2 variety of Spanish. 


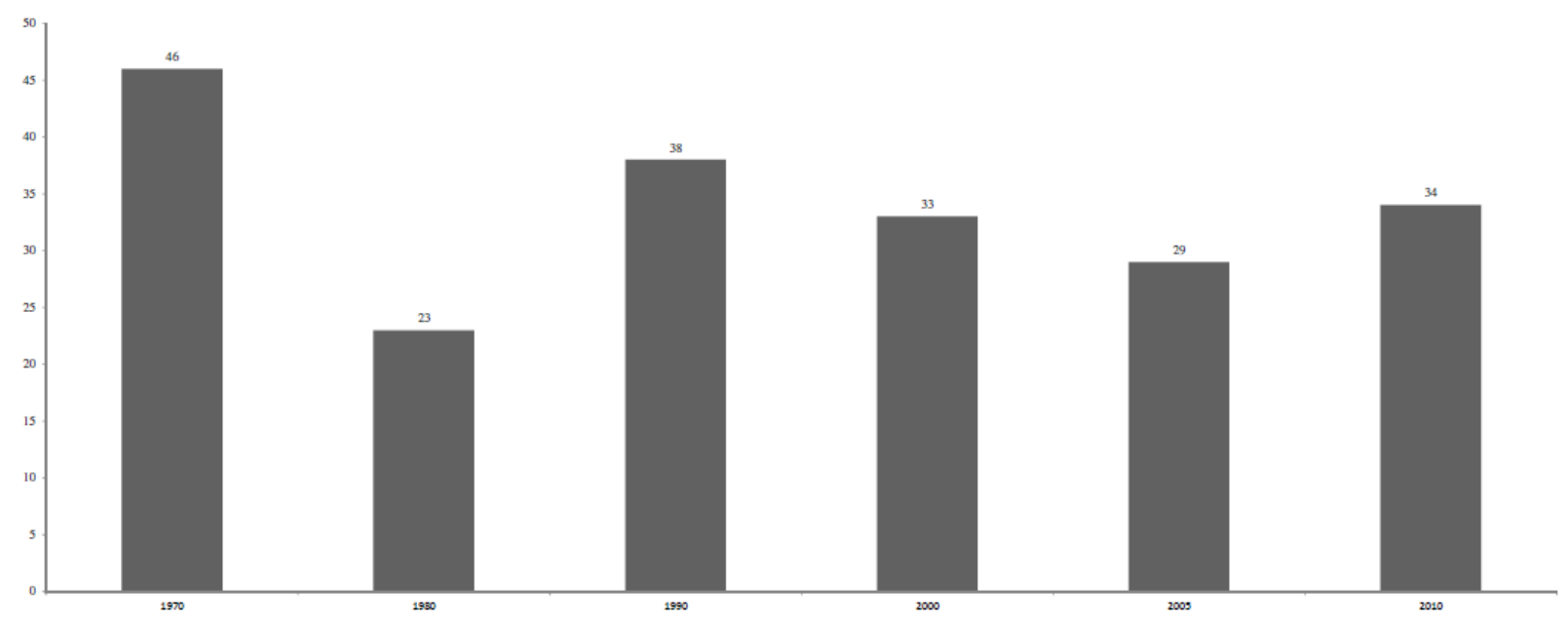

Figure 2: Maya speakers as percentage of total population in Yucatan state. Source: INEGI.

Importantly, while Maya speakers have slowly abandoned their native language in favor of Spanish over the past centuries (Pfeiler \& Zámišová 2006), the Maya language enjoys a level of prestige uncommon among indigenous languages in Latin America. Lope Blanch (1987: 9) observes that the prestige of Maya may be due to several factors, including its status as an adstrate, rather than substrate, language; the relatively large percentage of the population that still speaks Maya, including city dwellers; and the existence of a single indigenous language throughout the territory, in comparison to other areas with many small, mutually unintelligible languages. Additionally, the use of Maya phrases has a certain popularity among some, particularly young, Spanish speakers (see Michnowicz 2008: 298-299; Kolmer 2006). These factors have led numerous researchers to attribute a wide-variety of linguistic features of Yucatan Spanish to Maya language influence, with Lope Blanch (1987: 8-9) stating while in many contact varieties features are erroneously attributed to the indigenous language, "[t]his is not the case with Yucatan Spanish. In it, the influence of the Maya language is patently clear, and cannot be argued" (my translation). Likewise, Klee (2009) and Lipski (2004) identify Yucatan as one of the three regions most likely to demonstrate indigenous influence, along with Paraguay and the Andean region.

\section{Linguistic consequences of Maya-Spanish contact}

Before beginning the discussion of possible areas of Maya influence on Yucatan Spanish, it is important to distinguish between L2-interference features on the one hand, that for the most part only occur among the bilingual, Maya-dominant population, and on the other hand, possibly Maya-influenced features that have also permeated the Spanish of monolinguals, likely through processes of large-scale shift of Mayaspeaking populations to Spanish over the last century or more (see Thomason \& Kaufman 1988; Winford 2003 for an overview of these processes). This distinction is also important in other areas of indigenous language contact, such as the Andes (Escobar 2011: 328). Although there are some exceptions, generally speaking, phonetic/phonological variants are more likely to have been passed to the monolingual Spanish population than morpho-syntactic variants, which are primarily restricted to bilingual speech (see Escobar 2011 for a comparison with Quechua influenced Spanish in the Andes, where similar patterns exist).

\subsection{Phonetics/Phonology}

The phonetics/phonology of Yucatan Spanish, frequently attributed to Maya contact, represent the most studied area of the dialect. Lope Blanch (1987: 34) provides an overview of phenomena that have been attributed, rightly or wrongly, to contact with Maya. These include the substitution of [p] for $/ \mathrm{f} /$, as in ['pe.fas] for fechas (Michnowicz 2012; Suárez 1979); the elision of $/ \mathrm{x} /$, as in [tra.'ba.o] for trabajo (Michnowicz 2012; Barrera Vásquez 1937); and the depalatalization of /n/, as in ['ni.njo] for niño 
(Barrera Vásquez 1937; Yager 1982). Most of these features, however, have not been systematically analyzed in the literature. Therefore, the discussion below will focus on the main phonetic variables analyzed in previous work.

\subsubsection{Final -m}

One of the most studied features of Yucatan Spanish is the possibility of labializing word final nasals in absolute final position (i.e. before a pause), where most other varieties allow only [n] or [n], for example pan ['pam] or camión [ka.'mjom] (Michnowicz 2006, 2007, 2008; Alvar 1969; Cassano 1977; Yager 1982, 1989; García Fajardo 1984; Lope Blanch 1987, 1990; Pfeiler 1992). Michnowicz (2008: 289) found $25 \%[\mathrm{~m}]$ in absolute final position, although that frequency may be much higher for particular lexical items, such as place names (Michnowicz 2006). Importantly, this same alternation appears in Maya as well, for example hun "one" can be realized as [hum] (Bolles \& Bolles 2001). Final -m appears to be a relatively recent innovation, not appearing in early studies of the dialect (such as Barrera Vásquez 1937, Nykl 1938, Mediz Bolio 1951), and is increasing in use among younger speakers of Yucatan Spanish (Yager 1989, Michnowicz 2007, 2008). Final - $\mathrm{m}$ is also more frequent among women than men (Yager 1989, Pfeiler 1992, Michnowicz 2007, 2008), and appears to be a linguistic marker of Yucatan identity. While most studies have attributed -m to Maya contact (e.g. Alvar 1969, Yager 1982, Lope Blanch 1987), the presence of $-\mathrm{m}$ in other dialects (i.e. in particular parts of Colombia; Lipski 2004; Canfield 1981) leads Cassano (1977) to outright reject any influence from Maya. More recent quantitative studies disagree with respect to direct Maya influence. Yager (1989) found no significant difference between language groups, while Michnowicz $(2007,2008)$ showed that Maya speakers produced significantly more $-m$ than did Spanish monolinguals (32\% -m vs. 19\%, respectively; Michnowicz 2008: 292). The most likely scenario is probably that outlined by Lope Blanch (1987: 62-63), who argued that -m in Yucatan is the result of an internal process in Spanish that has been favored by Maya contact, arising first among bilingual speakers and then passing to monolinguals through contact. This feature has also been attested in varieties in contact with Guaraní in Paraguay, although it is a declining form in that country (Granda 1982; see Klee \& Lynch 2009 for a summary).

\subsection{2/bdg/}

Another feature of Yucatan Spanish frequently attributed to Maya contact is the occlusive realization of $/ \mathrm{bdg} /$ in positions that would normally favor approximants, including intervocalically, for example todo ['to.do] or yo vivo ['jo.' bi.bo] (Michnowicz 2009, 2011, 2012; Alvar 1969; Cassano 1977; Yager 1982; García Fajardo 1984; Lope Blanch 1987, 1990). Previous reports on /bdg/ are inconsistent, ranging from Alvar (1969: 165) who noted almost categorical occlusives, to later studies such as Yager (1982: 58) who reported high rates of stops, but also a slight preference for approximants. Complicating the issue, some researchers also report occasional relaxed articulations (Suárez 1979, García Fajardo 1984). Most recently, Michnowicz (2011: 198) found 42\% [b], 32\% [d] and 28\% [g] in spontaneous speech. Regarding Maya influence, most studies propose a combination of factors, including Spanish-internal processes and a possibly indirect influence from Maya (Cassano 1977, Yager 1982). Michnowicz (2009) argued that stop [bdg], common in L2 varieties of Spanish around the world, is a case of a fossilized L2 feature that, like -m, has spread from bilinguals to the monolingual populace, through processes of large-scale shift (Thomason \& Kaufman 1988). Michnowicz (2011: 201-202) found that fluent Maya-speakers produced significantly more stops than Spanish-monolinguals, by an average of $15 \%$. Likewise, speakers over age 30, exposed to more Maya and Maya-influenced Spanish than younger speakers, also produced significantly more stops than younger speakers (Michnowicz 2011: 202).

\subsection{3 /ptk/}

In both bilingual and monolingual Yucatan Spanish, the voiceless stops /ptk/ are often aspirated to levels not ordinarily found in Spanish, for example pan [' $\mathrm{p}^{\mathrm{h}} \mathrm{an}$ ] or tomas [' $\mathrm{t}^{\mathrm{h}} \mathrm{o}$. 'mas] (Michnowicz 2012; Michnowicz \& Carpenter MS; Nykl 1938; Suárez 1979; Alvar 1969; Yager 1982; García Fajardo 1984; 
Lope Blanch 1987, 1990). Many studies, noting the existence of both aspirated and ejective stops in Maya, argue for direct Maya influence (Nykl 1938, Yager 1982), while others suggest that, like /bdg/, aspirated /ptk/ are likely due to indirect influence (Coupal \& Plante 1977; Lope Blanch 1987). Studies also report differences in the degree of aspiration in Yucatan Spanish. Suárez (1945) stated that aspiration is one of the characteristic features of the dialect, while Alvar (1969) reported that while aspiration is greater than that typical of Spanish, it does not reach levels of aspiration in English ${ }^{2}$. Coupal \& Plante (1977), one of very few instrumental studies of Yucatan /ptk/, noted that aspiration (VOT) is not as long as some would suggest, but that it is greater than that found in the Caribbean or Spain (p. 150). More recently, Michnowicz \& Carpenter (MS) ${ }^{3}$ found mean VOTs of $17 \mathrm{~ms}, 22 \mathrm{~ms}$ and $34 \mathrm{~ms}$ for $/ \mathrm{ptk} /$ respectively, somewhat longer than many other varieties of Spanish, but not as aspirated as some early studies would suggest. In agreement with Lope Blanch (1987), who reports a wide range of individual difference for aspiration, Michnowicz \& Carpenter (MS) found VOT ranges much larger than other dialects; between $75 \mathrm{~ms}$ and $122 \mathrm{~ms}$ for Yucatan, compared with ranges between $21 \mathrm{~ms}$ and $43 \mathrm{~ms}$ for Castilian Spanish (Rosner et al. 2000). Thus while the overall mean VOT value is only slightly greater than in other dialects, the wide range of values indicates that at times /ptk/ is aspirated to a great degree, but not consistently across tokens (see also Yager 1982). Younger speakers generally have shorter (more like standard Spanish) VOTs than older speakers (Michnowicz \& Carpenter MS). Regarding direct Maya influence, Michnowicz \& Carpenter (MS) found no consistent pattern for VOT measurements by language; in a fixed-effects model, Maya speakers produced significantly longer VOTs for $/ \mathrm{k} /$, but Spanish speakers had significantly longer VOTs for $/ \mathrm{t} /$, with no significant difference between languages for $/ \mathrm{p} /$. The authors do not, however, discard the possibility of Maya influence, and note that such influence may have occurred in the past. If Maya has played a role in aspirated /ptk/, then the process of transfer to monolingual speakers may be further along than for $/ \mathrm{bdg} /$, thereby obscuring the effect for bilingualism that may have existed at an earlier period.

\subsubsection{Glottalizations and / // insertion}

The literature on Yucatan Spanish distinguishes between glottalized (or ejective) consonants, and the insertion of a glottal stop / $/$ / in a variety of contexts, but most frequently between two vowels of different quality, for example me iba [me.' 'Pi.ba] or doce años ['do.se.' 'a.nos] (Lope Blanch 1987: 115). Stress also plays a role, with stressed vowels favoring /?/ insertion (Yager 1982: 88). Truly ejective consonants, common in Maya, rarely surface in Yucatan Spanish (Lope Blanch 1987: 103), with the exception of names of flora and fauna of Maya origin, and even then only among bilingual speakers. The insertion of $/ 2 /$, however, is more common, and is the focus of the little research done to date. Most researchers have concluded that his phenomenon is one of the strongest candidates for direct Maya influence on Yucatan Spanish (Barrera Vásquez 1937; Nykl 1938; Suárez 1979; Yager 1982; García Fajardo 1984; Lope Blanch 1987, 1990), based on the fact that Maya does not permit vowel initial words, and vowel-initial borrowings from Spanish are transferred to Maya with an epenthetic /2/, for example amigo is borrowed as [?áamigóoh] (Frasier 2009:23), a process that is lacking in most varieties of Spanish. Although detailed sociolinguistic analyses of / $/$ do not yet exist, some preliminary details are available. Lope Blanch (1987: 106) found / $/$ / insertion "with notable regularity in the Spanish of a good number of Yucatecans" (my translation), and García Fajardo (1984: 86-86) found that /?/ occurs most frequently among lower class speakers. Finally, Michnowicz (2012), in case studies examining two families, found / $/$ in vowel initial words an average of $19 \%$ for Maya speakers, compared with $7 \%$ for Spanish speakers, a significant difference. Likewise, older speakers produced significantly more $/ \mathrm{P} /$ than younger speakers, with the youngest speakers in both the Maya speaking and the Spanish monolingual families producing almost no

\footnotetext{
${ }^{2}$ (Lisker \& Abramson 1964: 394 report mean values of 58ms for $/ \mathrm{p} /, 70 \mathrm{~ms}$ for $/ \mathrm{t} / \mathrm{and} / 80 / \mathrm{ms}$ for $/ \mathrm{k} / \mathrm{in}$ English).

${ }^{3}$ This article has been submitted; if accepted for publication, the citation will be updated in the final draft of the article. This data was presented at the 6th Workshop on Spanish Sociolinguistics at the University of Arizona, April 2012.
} 
cases of / $/$ /. Michnowicz (2012) suggests that this variant may disappear as Maya speakers continue to shift to Spanish in ever greater numbers (see section 4 for further discussion). A similar pattern of / $/$ insertion has been reported for Guaraní-Spanish bilinguals in Paraguay and parts of Argentina, a feature also attributed to phonological patterns in the indigenous language (Granda 1982).

\section{$3.1 .5 / \mathbf{j} /$}

Yucatan Spanish, as is common across Spanish varieties, permits a wide variety of realizations of $/ \mathrm{j} /$. Using Solomon's (1999) terms, these realizations range from "weak" articulations, such as deletion or approximant [j], to "strong" allophones, such as [3] or [d]]. One of the most frequently commented forms is the elision of $/ \mathrm{j} /$ intervocalically, most frequently in contact with $/ \mathrm{i} /$, as in anillo [a.'ni.o] or gallina [ga. 'i.na] (see Alvar 1969, García Fajardo 1984). Suárez (1979) and García Fajardo (1984) both indicated that deletion of $/ \mathrm{j} /$ is most common among older, less educated speakers, and Maya bilinguals. Solomon (1999) compared weak forms (including deletion) to strong forms (primarily [d]], among others) for speakers in Valladolid, Yucatan. Her findings, consistent with earlier reports, showed a majority of weak variants (96\%), although most of these represent a weak approximate [j] rather than true deletion (p. 157). Weak variants were significantly favored by male gender, lower social class, and older age (p. 171). Regarding possible Maya influence, Solomon (1999) notes that in her recordings of Maya, speakers consistently employed a weak / $\mathrm{j}$ / in that language, suggesting that "fluent Maya speakers might therefore be more likely to use [j] in their Spanish" (p. 192). Likewise, many of her informants attributed this pronunciation in Yucatan Spanish to Maya influence (p. 192). The author points out, however, that language background and other social factors, such as age and social class, strongly overlap, and thus it is difficult to disentangle the possible effects of Maya influence from that of other factors (p. 193). Solomon (1999) closed by stating that, given that weakened / $\mathrm{j} /$ is common in other areas of Mexico and Central America, Maya contact may have supported the use of weak variants, but "...there is no convincing evidence that Maya [/j/] has had a central influence" (p. 194) on /j/ in Yucatan Spanish.

\subsubsection{Intonation}

Intonation is one of the most frequently commented, if least studied, possible contact features in Yucatan Spanish. Speakers of the dialect are conscious of differing intonational patterns that separate Yucatan Spanish from other varieties, and use terms such as pujado "pushed" to describe their accent. Yucatan Spanish intonation is described in the literature as "peculiar" (Barrera Vásquez 1945/1977: 341) and "slow and halting" (Suárez 1979: 77; my translations). Early researchers were also quick to attribute intonational differences to Maya contact (Nykl 1938; Barrera Vásquez 1937, 1945/1977; Mediz Bolio 1951; Suárez 1979). Mediz Bolio (1951: 19) observed that Yucatan Spanish intonation "is nothing else but a consequence of the original Maya accent" (my translation), also noting that this Maya-influenced pattern has permeated the monolingual Spanish-speaking population. Suárez (1979: 77) called Yucatan Spanish intonation "reflections of Maya phonetics" (my translation). Others have been more reserved, such as Lope Blanch (1987: 39), who argued that not enough is known about either Maya or Yucatan Spanish intonation to establish such a connection. Unfortunately, the lack of knowledge about Maya phrasal intonation is still limited, as most research has focused on the patterning of lexical tones (see Gussenhoven \& Teeuw 2008, among others). An initial attempt at exploring Yucatan Spanish intonation in spontaneous speech is found in Michnowicz \& Barnes (in press). They found that spontaneous Yucatan Spanish does display a higher rate of early $F_{0}$ peaks (that is, where the intonational peak is aligned with the stressed, rather than the post-tonic, syllable) than many other varieties of Spanish, with $64 \%$ of peaks aligning with the stressed syllable. As a point of comparison, Face (2003) found $25 \%$ early peaks in spontaneous Castilian Spanish. This peak alignment pattern, common in many contact varieties (Cuzco Spanish - O'Rourke 2004; Buenos Aires Spanish - Colantoni \& Gurlekian 2004), is employed in other dialects to mark focus or emphasis. This result, then, in part accounts for the emphatic, pausing nature of 
Yucatan Spanish intonation reported in earlier studies and noted by visitors and native speakers alike. Regarding direct Maya influence, a preliminary statistical analysis did not find a significant difference regarding peak alignment between Maya bilinguals and Spanish monolinguals in Yucatan (Michnowicz \& Barnes in press), a finding that supports Barrera Vásquez's (1937) observation that these two groups do not differ in their intonation. At the same time, the authors outlined a possible scenario in which Maya could have indirectly influenced peak alignment, noting that Maya, unlike Spanish, does not express focus or contrast through changes in prosody (see Frazier 2009, among others). This, combined with the observation that Maya high tones associate with phrase internal stressed syllables (see Gussenhoven \& Teeuw 2008), leads to the possibility that shifting Maya speakers, when faced with prosodic input that did not match their native language, could have adopted early peaks as a general strategy of simplification (Michnowicz \& Barnes in press; see also Colantoni 2011). This pattern, like /ptk/ or /bdg/ outlined above, could then have spread to the monolingual population through large scale shift. More research is needed to confirm or refute this possibility.

\subsection{Morpho-syntax}

Compared with phonetic/phonological features, there has been relatively little research done on morphosyntactic features in Yucatan Spanish. Many of the features that have been mentioned in the literature occur only among the bilingual population, and most likely are simple cases of L 2 forms employed by second language speakers of Spanish around the world (see Michnowicz 2012). These include variation in prepositions, such as voy con el doctor for voy al doctor (Barrera Vásquez 1937); lack of gender agreement, as in nos gusta ver nuestra ciudad limpio (Michnowicz 2012: 106); non-standard use of auxiliary verbs, such as tengo ido a Cozumel (Michnowicz 2012: 106); variation in the placement of clitics, for example la paciente tuvo que se internar a la urgencia (Michnowicz 2012: 107); and pleonastic lo, as in ¿no te lo da vergüenza? (Suárez 1979: 180). None of these features were found among monolingual Spanish speakers, and likely represent general interlanguage forms found in many L2 contact situations around the world, rather than features unique to Yucatan Spanish or direct transfer from Maya (Michnowicz 2012; compare similar forms in Andean Spanish (Escobar 2011), Guarani-Spanish (Gynan 2011), and L2 and Heritage Spanish in the United States (Montrul, Foote \& Perpiñán 2008)). Other features are more common, appearing also in the speech of some monolinguals, such as the use of pleonastic possessive pronouns, as in te cortaste tu dedo and su casa de Juan (examples from Suárez 1979: 179). Suárez (1979: 179) attributes this usage to transfer of the Maya genitive construction, which requires the possesive $U$ before the possessed noun; i.e. $U N O K$ ' IN SUKUUM $\sim$ su ropa de mi hermano, although similar constructions also appear elsewhere in Spanish dialects. This feature, like the others outlined above, has never been systematically studied, and the discussion below will address three morpho-syntactic features that have been addressed in more detail in the literature.

\subsubsection{Subject pronoun expression}

Yucatan Spanish, along with other varieties of Spanish, is a pro-drop language, in which a subject may or may not be expressed according to a variety of contextual, syntactic and other factors (see Otheguy \& Zentella 2012 for a detailed description of pro-drop in Spanish); for example, both hablo and yo hablo are acceptable structures in Spanish. Various researchers have proposed that contact with a language that requires a subject pronoun, such as English, can lead to higher pronoun rates (Otheguy \& Zentella 2012 provide an overview). Additionally, other studies have suggested that contact with any language, even another pro-drop language, can also lead to higher pronoun rates, as bilingual speakers employ more subject pronouns as a simplification strategy (e.g. Sorace 2004). Other studies, however, have not found such an effect (de Prada 2009). As Maya, like Spanish, is arguably a pro-drop language (see Solomon 1999: 225 for examples; but see Norcliffe 2009 for arguments against a traditional pro-drop analysis of 
Maya $^{4}$ ), data from Yucatan Spanish can contribute to the debate in the literature. Solomon (1999) demonstrates that the overall rate of expressed pronouns in her data from Valladolid, 19\%, does not differ greatly from the rate found for other mainland varieties (cf. 24\% expressed pronouns for recently arrived mainlanders in New York City - Otheguy \& Zentella 2012: 108). Michnowicz (in press), in a study carried out with speakers from in and around Merida, also found a similar rate of $20 \%$ overt pronouns. Additionally, many of the same linguistic factors found to favor expressed pronouns in other varieties, such as switch reference, were also significant predictors in both Valladolid and Merida (Solomon 1999: 250; Michnowicz in press). Regarding direct Maya influence, Maya has a very low rate of overt subject pronouns (but see footnote 4 below) - 8\% in Solomon (1996, summarized in Solomon 1999:225). Studies differ, however, with regards to differences between bilinguals and monolingual Spanish-speakers. While Solomon (1996) found no significant differences between bilinguals and monolingual Spanish-speakers with regard to pronoun expression, Michnowicz (in press) did find a significant effect for language, with Maya bilinguals producing significantly more overt pronouns than Spanish monolinguals (24\% vs. 16\% overt respectively). This difference may be due to methodology, as Solomon (1996) is a very small pilot study, with between 105-186 total tokens, compared with almost 2000 tokens in Michnowicz (in press). Following Sorace (2004), Michnowicz (in press) attributes this difference in pronoun rate to a possible simplification strategy on the part of Maya speakers.

\subsubsection{Impersonal verb constructions with agentive por}

Another structure addressed briefly in previous literature is the existence of the plural impersonal verb with agentive por-phrase construction.

Se lo llevaron por el viento for se lo llevó el viento

Lo castigaron por su papá for lo castigó su papá (examples from Barrera Vásquez 1937: 9)

Barrera Vásquez (1937: 9) attributes this construction to a "literal translation of Maya syntax" (my translation), viewing the Yucatan Spanish se lo dijeron por su papá as a direct gloss of the Maya 'álab ti' tumen u tata' (Barrera Vásquez 1943: 94). Lema (1991: 1283-1285) provides the following analysis of this phrase in Maya:

\begin{tabular}{|l|l|l|l|l|l|l|}
\hline al & a & b & ti' & tumen & u & tata' \\
\hline $\begin{array}{l}\text { 'to } \\
\text { say' }\end{array}$ & $\begin{array}{l}\text { reduplicative } \\
\text { vowel }\end{array}$ & $\begin{array}{l}\text { causal } \\
\text { morpheme }\end{array}$ & $\begin{array}{l}\text { indefinite pronoun [-1st } \\
\text { per; - 2nd per] }\end{array}$ & $\begin{array}{l}\text { Causal } \\
\text { preposition }\end{array}$ & Possessive & father \\
\hline
\end{tabular}

Table 1. Analysis of phrase "álab ti’ tumen u tata” (Lema 1991).

Lema (1991) argues that the influence from Maya in the previous example is not syntactic, but rather semantic, in nature. For Lema (1991), this construction is related to the notion of causality in Maya, where a phrase such as "they are killing me" ("me matan" in Spanish) is expressed in Maya as "I am being affected by someone who is causing me to die" (p. 1284, my translation, following Tozzer 1977). The causal morpheme ' $b$ ' and preposition 'tumen' in Maya are identified with the existing (non-standard) Spanish construction with por, as in se firmó la paz por los embajadores (citing Gili Gaya 1976), which allows for a prepositional phrase headed by por to act as the subject of an impersonal phrase with se.

\footnotetext{
${ }^{4}$ Maya possesses a series of obligatory agreement markers that indicate person and number, which make a coindexed NP optional in the syntax(Norcliffe 2009; Bolles \& Bolles 2001); at the same time, there do exist independent subject pronouns, but these "have a highly restricted function, occurring only in topic or focus position, or following prepositions" (Norcliffe 2009: 143-144).
} 
Also, the verb in the Yucatan Spanish construction appears in the plural, reflecting "the indefiniteness of the referent of the syntactic subject, without a morpheme in Maya, which indicates [-1st] and [-2nd] person. This indeterminacy in Spanish is marked with the plural ending on dijeron" (p. 1285, my translation). It is noted, therefore, that "causality between Maya and Spanish is reinforced, the indefiniteness of the subject is transmitted, and the importance of the indirect is underlined" (Lema 1991: 1285). For this construction, it is argued that contact with Maya led to a reinforcement of an already (marginally) existing pattern in Spanish. Additionally, while Suárez (1979: 181) observes that this construction is only found among lower class rural speakers, Lema (1991) argues that it occurs frequently across all social and demographic groups, therefore suggesting that this is not unique to bilingual populations.

\subsubsection{The pluralization of impersonal haber}

In normative Spanish, existential or impersonal haber prescriptively does not agree with its accompanying nominal phrase, which syntactically is analyzed as a direct object rather than a subject. In spoken Spanish, however, this construction is often reanalyzed by speakers, with the verb agreeing in number with what speakers perceive to be the subject. Compare standard habia muchas personas with colloquial habian muchas personas. This feature is not unique to Yucatan, and occurs throughout the Spanish-speaking world (see Bentivoglio \& Sedano 2011). Castillo-Trelles (2007) presents a quantitative analysis of this phenomenon in Yucatan Spanish, where she finds an overall rate of 53\% pluralization in conversational data (p. 80), similar to rates found in other varieties (see Bentivoglio \& Sedano 2011: 173 for an overview). Although language background was not a significant factor in the oral data, Maya bilinguals did significantly favor pluralization over Spanish monolinguals in a questionnaire task, in which the participants had to indicate which form (singular or plural) they would use in a series of phrases (Maya bilinguals $=65 \%$ pluralization; Spanish monolinguals $=42 \%)(\mathrm{p} .81)$. Although Castillo-Trelles does not hypothesize about the possible causes of the observed differences, it is likely that language background overlapped significantly with education level, which was not selected as significant in the statistical analysis. As the pluralization of haber is a universal phenomenon in Spanish, it is unlikely that the observed pattern can be attributed to either direct or indirect Maya influence. These findings do illustrate, however, the ways in which language background and social class/education level frequently interact in modern day Yucatan.

\subsection{Lexical borrowing}

Lexical borrowing is especially prevalent in situations of language contact, even when that contact is not particularly intense, given that speakers do not even need to be functionally competent in the lending language in order to borrow words (Winford 2003: 30-31). This is particularly true for items or concepts that are foreign to the receiving language, such as terms for local flora and fauna. Both of the contact languages in Yucatan have undergone heavy cross-linguistic influence in their lexicons, although Maya has borrowed significantly more from Spanish than vice-versa, including even basic terms, such as numbers above four (Bolles \& Bolles 2001). The Spanish of Yucatan, in contrast, has not adopted Maya terms for any of its core vocabulary - or at the very most when a Maya equivalent has been borrowed (such as Chichi for grandmother), the native Spanish form (abuela) continues to exist, often as a formal variant alongside the indigenous borrowing (see also Kolmer 2006). Suárez (1979) provides a detailed summary of borrowings into Yucatan Spanish, a few of which are presented in the table below.

\begin{tabular}{|l|l|l|l|}
\hline Food & & & \\
\hline Pibil & $\begin{array}{l}\text { Cooked underground; ex. } \\
\text { pollo pibil }\end{array}$ & K'abik & A regional stew \\
\hline
\end{tabular}




\begin{tabular}{|c|c|c|c|}
\hline Xix & Crumbs & Papasul < Papak'sul & $\begin{array}{l}\text { A regional dish with } \\
\text { tortillas, eggs and sauce } \\
\text { made from squash }\end{array}$ \\
\hline \multicolumn{4}{|c|}{ Flora \& Fauna } \\
\hline Ch'om & Vulture & Chinchibakal & A type of songbird \\
\hline Xux & Wasp & Xmahanna & A type of large moth \\
\hline \multicolumn{4}{|c|}{$\begin{array}{l}\text { Local } \\
\text { customs/folklore }\end{array}$} \\
\hline Hanalpixán & $\begin{array}{l}\text { Yucatan version of } \\
\text { Mexican Day of the Dead }\end{array}$ & $\begin{array}{l}\text { Mukbipollo < Maya Mukbil } \\
\text { "cooked underground"; } \\
\text { Spanish "pollo" }\end{array}$ & $\begin{array}{l}\text { A type of tamal, eaten } \\
\text { especially during } \\
\text { Hanalpixán }\end{array}$ \\
\hline Xtabay & $\begin{array}{l}\text { Legendary female spirit in } \\
\text { Yucatan; similar to } L a \\
\text { Llorona in Mexico }\end{array}$ & Alux & $\begin{array}{l}\text { Small, legendary spirits } \\
\text { or elves that inhabit } \\
\text { Maya ruins. }\end{array}$ \\
\hline
\end{tabular}

Table 2. Sample lexical borrowings from Maya in Yucatan Spanish

In addition to the expected cultural borrowings above, common in most, if not all, cases of language contact, Maya terms have also entered colloquial Yucatan Spanish, and are used by all levels of society, regardless of language background. Kolmer (2006) observes that these Maya loans are becoming increasingly popular among speakers of Yucatan Spanish, perhaps as a way of expressing a sense of local pride and identity (a trend also seen with some other features of Yucatan Spanish; see for example the discussion on final -m above; Michnowicz 2008). Examples of these common terms include (all examples from Kolmer 2006: 185-186).

Nouns such as tuch "bellybutton", as in hoy Juan se rasca el tuch (lit. "today Juan is scratching his bellybutton"; i.e. Juan is not doing anything today).

Adverbs, such as chan "a little" - ella lo chan quiere (she loves him a little); or hach "very much" - me hach gusta ese traje (I like that suit very much). Interestingly, these adverbs directly precede the verbs they modify, copying their preferred position in Maya (Kolmer 2006: 185), even intervening between the verb and the clitic pronoun, a position not normally licensed in Spanish ${ }^{5}$.

Adjectives, such as kuch "tasteless; tacky" - está muy kuch tu sombrero (your hat is very tacky)

Interjections, such as ;huy! to express fear or anxiety; or chuch, used to reinforce an expression, as in ¡Chuch, qué bueno!

Another interesting category of lexical borrowing is the use of hybrid Maya-Spanish verb phrases constructed with the Spanish verb hacer (Suárez 1977: 130). Common expressions in this category

\footnotetext{
${ }^{5}$ An anonymous reviewer points out the possibility that these adverbial expressions are borrowed as chunks or as fixed parts of an expression, rather than as a direct transfer of a Maya adverb to Spanish. More research is needed.
} 
include: hacer loch "to hug", as seen on a popular t-shirt ¿Me haces loch?; hacer puts' "to flee from an obligation", as in hoy hago puts' trabajo (today I'm skipping work; example from Kolmer 2006: 187)'.

My own fieldwork suggests that Maya phrases such as these are often employed by younger speakers of the middle and upper social classes (see also Kolmer 2006). One informant, a 25 year old college graduate, notes that among his group of friends, a stereotypical Yucatan accent and Maya phrases are often used for comic effect:

Eh, no sé...es un acento muy chistoso, muy alegre, muy risueño. Y al mezclarlo también con palabras mayas y todo, pues da risa, y es muy agradable ${ }^{7}$.

At the same time, this speaker notes that the use of Maya terms can also be a way to signal in-group identity, in the face of increased contact with those from outside of Yucatan (see Michnowicz 2011, 2012).

...y este igual nos da mucha gracia, que gente del exterior no las entiende [palabras mayas] y nosotros nos reímos ${ }^{8}$.

\section{The future of Maya-Spanish contact in Yucatan}

When considering the future of Maya-Spanish contact in Yucatan, it is important to keep in mind that there are at least two factors involved: First, the demographics of the Maya-speaking population, as obviously sustained language contact is dependent on the continued presence of both languages in Yucatan. This of course includes not only Maya monolinguals, but also Maya-Spanish bilinguals, that can serve as a locus for cross-linguistic influence; and second, the extent to which Maya-influenced forms have directly or indirectly impacted the Spanish spoken by the monolingual majority, and therefore may continue on as vestiges of contact independent of the demographics.

As noted in section 2, the number of Maya speakers in the State of Yucatan has steadily declined over the past half century (INEGI), although differing methodologies and questionnaires in different years of the Mexican census make it difficult to know exactly how many Maya speakers remain. The latest census (2010) reports that approximately 660,000 people in the State of Yucatan speak an indigenous language (overwhelmingly Maya). This figure represents $34 \%$ of the total population of Yucatan, up slightly from the 2005 census numbers, but in-line with those reported for 2000 (see Figure 2). Still, the overall trend is one of decline, as more and more speakers become bilingual, followed by a shift, often by the children of these bilingual speakers, to Spanish (see Pfeiler \& Zámišová 2006). Cifuentes \& Moctezuma (2006: 191) use a series of four indicators of language vitality to examine questions of indigenous language maintenance and shift in Mexico: 1) the residence of indigenous language speakers in their ancestral homelands; 2) the rate of growth seen in the indigenous speaking community; 3) the levels of Spanishindigenous language bilingualism; 4) the use of the indigenous language within the home. According to Cifuentes \& Moctezuma (2006), Maya does fulfill the first characteristic, with a vast majority of Maya speakers residing in their native homelands on the Yucatan peninsula (p. 220), thereby lending support to the maintenance of Maya. The other three indicators, however, point toward language shift to Spanish, and they classify Maya as one of a group of indigenous languages in which "[w]e notice the last stages of bilingualism and the initial stages of shift towards Spanish monolingualism" (p. 240). One of the factors

\footnotetext{
${ }^{6}$ Note that this construction is not unlike the hacer + English stem form reported for Spanish in the United States, e.g. "...no quería hacer open..." “...she did not want to open [the gate]...” (Toribio 2011: 538-539).

7 “Um, I don't know...it's a very funny accent, very happy, very cheerful. And when it is mixed with Maya words and such, well it makes us laugh, and it is very nice".

8 “.... and we also think it is funny, that people from elsewhere do not understand Maya words, and we laugh".
} 
that lead Cifuentes \& Moctezuma (2006) to this conclusion is the high rate of bilingualism present in this group of shifting languages, which is as high as $91 \%$ for Maya (p. 240; see also INEGI). While it is still possible to find Maya monolinguals (mostly older adults) in rural zones of the peninsula, the situation in the cities is quite different. In cities such as Merida, for example, many Maya-speakers use that language only rarely, as Maya use is restricted to familial and other semi-private contexts (Güémez Pineda 1994). At the same time, other researchers have noted the vibrancy of Maya compared to other indigenous languages in Latin America (see Lope Blanch 1987). As noted above, the fact that most Maya speakers live in their ancestral homeland on the Yucatan peninsula rather than being scattered throughout the country due to internal migrations can reinforce both the use of Maya (Cifuentes \& Moctezuma 2006), as well as the level of prestige attributed to the indigenous language (Lope Blanch 1987). In fact, the urban pattern of Maya use mostly in the home domain, noted by Güémez Pineda (1994) as a potential weakness, is seen by others as a sign of possible vitality in the future, or at least as a constraint on the ultimate shift to Spanish (Cifuentes \& Moctezuma 2006).

In light of the slow but sure decline of Maya in Yucatan, some attempts have been made to revitalize the Maya language through various educational and cultural programs. Beginning in the 1940s, the government, along with civil associations, has undertaken various projects to promote the use of Maya in Yucatan, with mixed results (Pfeiler \& Zámišová 2006). For example, the Academia de la Lengua Maya de Yucatán, founded in 1937 by Alfredo Barrera Vásquez, lists as one of its main goals "the promotion of oral and written expression in Maya" (my translation), and its efforts include the recent publication of the Diccionario Maya Popular, published in 2003. In 2003, the Mexican government promulgated the General Law on Linguistic Rights of Indigenous Peoples (Ley General de Derechos Lingüisticos de los Pueblos Indigenas), which guarantees the right of speakers to employ indigenous languages "for any matter or transaction of a public nature" (see Althoff 2006; Pellicer, Cifuentes \& Herrera 2006 for discussion). At the same time, in spite of these efforts and legal protections, the use of Maya, along with other indigenous languages in Mexico, continues to decline.

Bilingual education, as implemented in Yucatan, has been shown to lead to both maintenance of Maya and increased shift to Spanish, depending on the way the programs are designed. Pfeiler \& Zámišová (2006) compared two different approaches to bilingual education in Yucatan. The first of these, established by the Dirección General de Educación Indigena (DGEI), is the larger of the two programs examined, with almost 14,000 children enrolled in 2003 (Pfeiler \& Zámišová 2006: 291). Pfeiler \& Zámišová (2006) are critical of this program, however, noting that its primary goal is one of Hispanization of the indigenous population; in other words, the goal of the program is not to promote Maya language use per se, but rather to provide a bridge to allow Maya speaking students to master Spanish, thereby leading to increased shift (p. 294). The authors contrasted this program with another implemented by the Consejo Nacional de Fomento Educativo (CONAFE), which first instructs indigenous students in their native language, before exposing them to the L2 (Spanish). The goal of the CONAFE program is "conscious bilingualism", in which "the student values both his/her mother tongue and its surroundings: the Spanish language within its own context" (Pfeiler \& Zámišová 2006: 293). The authors noted that programs of this type lead to increased maintenance of Maya, but unfortunately do not receive the same support as the DGEI program, only enrolling 749 children during 2003 (p. 291). Bilingual education, then, in and of itself is necessary but not sufficient for Maya to be maintained in the long term.

Thus, while the sheer numbers of speakers ensures that Maya is unlikely to disappear in the near future, the high levels of Maya-Spanish bilingualism among the indigenous population suggests that the shift to Spanish has in large part already taken place (see Cifuentes \& Moctezuma 2006). In the short term, increased bilingualism also intensifies, in a technical sense, the level of language contact, since it is

${ }^{9}$ http://www.mayas.uady.mx/institutos/ins $04 . \mathrm{html}$ 
ultimately in the minds and speech of bilinguals that systematic interference can arise (as opposed to lexical borrowing, for example, which does not require bilingualism; see Winford 2003: 23-24 for an overview of different outcomes of language contact). At the same time, however, educational opportunities - in Spanish - are reaching the indigenous population at levels unthinkable several decades ago. Whereas previously bilingual speakers in small towns or rural areas would have had few opportunities to interact with or acquire monolingual varieties of Spanish, today young people of Maya background are exposed to urban, standard Spanish through media, education, and face to face interactions with monolingual Spanish-speakers. One result of this exposure, as demonstrated in Michnowicz (2012), is that young speakers from Maya-speaking families have largely abandoned the L2 interlanguage forms employed by their parents' and grandparents' generations.

The second aspect of Maya-Spanish contact is the use of possibly Maya influenced features by middle or upper class, monolingual Spanish-speakers in cities like Merida. Not surprisingly, given the patterns of standardization for Maya youth outlined above, younger speakers of Yucatan Spanish are also quickly abandoning many of the regional variants that define traditional Yucatan Spanish as described in the literature on the dialect. This has been shown to be the case for aspirated /ptk/ (Michnowicz \& Carpenter MS; Michnowicz 2012); occlusive /bdg/ (Michnowicz 2012, 2011, 2009); and /P/ insertion (Michnowicz 2012). Surprisingly, it has been shown that young speakers, whether from Maya or Spanish backgrounds, produce very similar, low rates for these features, showing that standardization appears to be happening in a similar fashion (and likely for similar reasons) across Yucatecan society (Michnowicz 2012). On the other hand, while some contact forms are quickly disappearing, research suggests that other variants possibly attributable to Maya contact are holding steady (such as peak alignment in intonation ${ }^{10}$ ) or increasing among some segments of the population, either as an indicator of identity or as a playful stereotype (such as final -m; see Michnowicz 2006, 2007, 2008; Yager 1989).

In conclusion, Maya-Spanish contact in Yucatan has produced a unique variety of Spanish, spoken by both bilinguals and monolinguals alike. Many traditional features of Yucatan Spanish, frequently attributed to Maya contact, are also standardizing at a rapid rate. This standardization, brought about by a confluence of social, political, and demographic factors, is reducing or eliminating many of the contactinduced forms from monolingual speech (see Michnowicz 2012, 2011; Klee 2009). At the same time, an increased shift of Maya speakers to Spanish is putting the contact situation that has developed over the last few hundred years at risk of extinction. More studies are needed that examine how these processes of standardization and language shift are playing out across Yucatan. Analysis of this situation, and others like it throughout Latin America, provide a window through which we can observe how speakers of indigenous languages shift to Spanish and the linguistic consequences thereof, a process that must have occurred throughout most of Latin America in the past, but is now only observable on a large scale in a few remaining enclaves of indigenous language use. At the same time, further attention from scholars can help shed light on how to best help Maya-speaking communities maintain their language for the foreseeable future.

\section{References}

AlthofF, F. Daniel (2006): “Centralization vs. Local initiatives. Mexican and U.S. legislation of Amerindian languages". In: Hidalgo, Margarita (ed.): Mexican indigenous languages at the dawn of the Twenty-First century. Berlin: Mouton de Gruyter, pp. 167-190.

Alvar, Manuel (1969): “Nuevas nOtAS SOBRE El ESPAÑOl DE YuCATÁN”. In: IBEROROMANiA, I, PP. 159-189.

BARRERA VÁSQUEZ, Alfredo (1937): “Mayismos y voces mayas en el español de Yucatán”. In: Investigaciones lingüisticas, 4, pp. 9-35.

\footnotetext{
${ }^{10}$ See Michnowicz \& Barnes (in press), and compare intonation in Buenos Aires Spanish for insight on how contact-induced intonation can persist long after the contact situation has ceased (Colantoni 2011, among many others).
} 
Bentivoglio, Paola/Sedano, Mercedes (2011): "Morphosyntactic Variation in Spanish-Speaking Latin America". In: Díaz-Campos, Manuel (ed.): The Handbook of Hispanic Sociolinguistics. Oxford: Wiley-Blackwell, pp. 168-186.

BOLles, David/Bolles, Alejandra (2001): A Grammar of the Yucatecan Mayan Language. Lancaster, California: Labryrinthos.

CANFIELD, D. Lincoln (1981): Spanish pronunciation in the Americas. Chicago: The University of Chicago Press.

CASSANO, Paul (1977): "La influencia del maya en la fonología del español de Yucatán”. In: Anuario de Letras, 15, pp. $95-113$.

CASTILlO-TRELlES, Carolina (2007): "La pluralización del verbo haber impersonal en el español yucateco". In: Holmqust, Jonathan/Lorenzino, Augusto/Sayahi, Lotfi (eds.): Selected Proceedings of the Third Workshop on Spanish Sociolinguistics. Somerville, MA: Cascadilla Proceedings Projects, pp. 74-84.

Cifuentes, Bárbara/MoctezumA, José Luis (2006): “The Mexican indigenous languages and the national censuses: 1970-2000". In: Hidalgo, Margarita (ed.): Mexican indigenous languages at the dawn of the Twenty-First century. Berlin: Mouton de Gruyter, pp. 191-245.

ColAntoni, Laura (2011): "Broad-focus declaratives in Argentine Spanish contact and non-contact varieties". In: Gabriel, Christoph/Lleó, Conxita (eds.): Intonational phrasing at the interfaces: cross-linguistic and bilingual studies in Romance and Germanic. Amsterdam: John Benjamins, pp. 183-212.

Colantoni, Laura/GurLeKIAN, Jorge (2004): "Convergence and intonation: Historical evidence from Buenos Aires Spanish". In: Bilingualism: Language and Cognition, 7, 2, pp. 107-119.

COUPAL, Lysanne/PlanTE, Claire (1977): “Las oclusivas sordas yucatecas: /ptk/: ¿Fuertes, aspiradas, glotalizadas?”. In: Langues et Linguistique, 3, pp. 129-176.

DE PRADA, Ana (2009): Subject expression in Minorcan Spanish: Consequences of contact with Catalan. Unpublished doctoral dissertation: Penn State University, State College, PA.

EsCOBAR, Anna María (2011): "Spanish in contact with Quechua". In: Díaz-Campos, Manuel (ed.): The Handbook of Hispanic Sociolinguistics. Oxford: Blackwell, pp. 323-352

FACE, Timothy L. (2003): "Intonation in Spanish declaratives: differences between lab speech and spontaneous speech". In: Catalan Journal of Linguistics, 2, pp. 115-131.

FrAZIER, Melissa (2009): The production and perception of pitch and glottalization in Yucatec Maya. Unpublished PhD Dissertation: The University of North Carolina - Chapel Hill.

García FAJARDO, Josefina (1984): Fonética del español de Valladolid, Yucatán. Mexico City: Universidad Nacional Autónoma de México.

GILI GAYA, Samuel (1976): Curso superior de sintaxis española. Barcelona: Vox.

GRANDA, Germán de (1982): “Observaciones sobre la fonética del español en el Paraguay”. In: Anuario de letras XX, pp. 145-194.

GÜÉMEZ PINEDA, Miguel A. (1994): "La lengua maya en Yucatán: una perspectiva sociodemográfica”. In: I'inaj, Semilla de Maiz, Revista de divulgación del patrimonio cultural de Yucatán, August, 1994. Online version: http://www.mayas.uady.mx/articulos/miguel.html

Gussenhoven, Carlos/Teeuw, Renske (2008): “A moraic and a syllabic H-tone in Yucatec Maya”. In: Herrera Z., Esther/ Butragueño, Pedro Martin (eds.): Fonología instrumental: Patrones fónicos y variación. Mexico City: El Colegio de México, pp. 49-71.

GynAn, Shaw N. (2011): "Spanish in contact with Guaraní". In: Díaz-Campos, Manuel (ed.): The Handbook of Hispanic Sociolinguistics. Oxford: Blackwell, pp. 353-373.

Instituto Nacional de Estadística y Geografía (n.d.): Censos y conteos de población y vivienda. $<$ http://www.inegi.org.mx/est/contenidos/Proyectos/ccpv/default.aspx?s=est\&c=16638>

KLEE, Carol A. (2009): "Migration and globalization: Their effects on contact varieties of Latin American Spanish", in: Lacorte, Manuel/Leeman, Jennifer (eds.): Español en los Estados Unidos y en otros contextos: Cuestiones sociolingüisticas, políticas y pedagógicas. Madrid/Frankfurt: Iberoamericana/Vervuert, pp. 39-66.

KLEE, Carol A./LYNCH, Andrew (2009): El español en contacto con otras lenguas. Washington, D.C.: Georgetown University Press. 
Kolmer, Katrin (2006): “¡Chuch, qué bueno! Vom Wiederaufblühen der Maya-Kultur und ihrer Präsenz im Spanischen von Mérida (Yucatán, Mexiko)". In: Romanistik in Geschichte und Gegenwart 12, 2, pp. 179-192.

LEMA, Rose (1991): "La estructura "se lo dijeron por su papá" del español yucateco. ¿"Simplemente tranportación de la sintaxis maya al español”?". In: Hernández, C./de Granada, G./Hoyos, C./Fernández, V./Dietrick, D/Carballera, Y. (eds): El español de América, Actas del III Congreso Internacional de El Español de América. Salamanca: Junta de Castilla y León, pp. 1279-85.

LEwIS, M. Paul (ed.) (2009): Ethnologue: Languages of the World,(16 ${ }^{\text {th }}$ ed.). Dallas, Texas: SIL International. Online version: http://www.ethnologue.com/.

LIPSKI, John (2004): El español de América (3rd ed.). Madrid: Catedra.

LiSKER, Leigh/ABRAMSON, Arthur S. (1964): “A cross-language study of voicing in initial stops: Acoustical measurements". In: Word, 20, 3, pp. 384-422.

LoPE Blanch, Juan M. (1987): Estudios sobre el español de Yucatán. México City: Universidad Nacional Autónoma de México.

Lope Blanch, Juan M. (1990): Atlas Lingüístico de México (dir). Mexico City: El Colegio de México Universidad Nacional Autónoma de México.

Mediz Bolio, Antonio (1951): Interinfluencia del maya con el español de Yucatán. Mérida, Mexico: Editorial Zamna.

MichnowicZ, Jim (2006): "Final - $\mathrm{m}$ in Yucatan Spanish: A Rapid and Anonymous survey". In Montreuil, J.P. (ed.): New Perspectives on Romance Linguistics. Vol. 2: Phonetics, phonology, and dialectology: selected papers from the 35th Linguistic Symposium on Romance Languages (LSRL). Amsterdam: John Benjamins, pp. 155-166.

MichNowicZ, Jim (2007): "El habla de Yucatám: Final -m in a dialect in contact”. In: Holmquist, Jonathan (ed.): Selected proceedings of The Third Workshop on Spanish Sociolinguistics (WSS3). Somerville, MA: Cascadilla Proceedings Project, pp. 38-43.

Michnowicz, Jim (2008): "Final nasal variation in Merida, Yucatan”. In: Spanish in Context, 5, pp. 278-303.

MichNowicZ, Jim (2009): "Intervocalic voiced stops in Yucatan Spanish: A case of contact induced language change?”. In: Lacorte, Manuel/Leeman, Jennifer (eds.): Español en Estados Unidos y en otros contextos de contacto. Madrid: Iberoamericana, 67-84.

Michnowicz, Jim (2011): "Dialect standardization in Merida, Yucatan: The case of (b d g)". In: Revista Internacional de Lingüistica Iberoamericana, 18, pp. 191-212.

MichNowicz, Jim (2012): "The standardization of Yucatan Spanish: Family case studies in Izamal and Mérida". In: Geeslin, Kimberly/Díaz-Campos, Manuel (eds.): Selected proceedings of the Hispanic Linguistics Symposium 2010. Somerville, MA: Cascadilla Proceedings Project, pp. 102-115.

Michnowicz, Jim/BARNeS, Hilary (In press): "Pre-nuclear peak alignment in Yucatan Spanish". To appear in the Selected proceedings of the Hispanic Linguistics Symposium 2011. Somerville, MA: Cascadilla Proceedings Project.

MichnOWICZ, Jim/CARPENTER, Lindsey (MS): "Voiceless stop aspiration in Yucatan Spanish". Presentation at the Sixth International Workshop on Spanish Sociolinguistics at the University of Arizona, Tucson, AZ. April, 2012.

Montrul, Silvina/Foote, Rebecca/PerpiÑán, Silvia (2008): "Gender agreement in adult second language learners and Spanish heritage speakers: The effects of age and context of acquisition”. In: Language Learning, 58, 3, pp. 503-553.

Mosely, Edward. H. (1980): "From conquest to independence: Yucatan under Spanish rule, 1521-1821," in Mosely, Edward./Terry, Edward. (eds.): Yucatan: A world apart. Alabama: University of Alabama Press, pp. 83-121.

NORCLIFFE, Elizabeth (2009): "Revisting agent focus in Yucatec". In: New Perspectives in Mayan Linguistics, 59, pp. 135-156. 
NYKL, Aloys. R. (1938): "Notas sobre el español de Yucatán Veracruz y Tlaxcala". In: Henríquez Ureña, Pedro (ed.): El español en Méjico, Los Estados Unidos, y la América Central. Buenos Aires: La Universidad de Buenos Aires, pp. 207-225.

O’Rourke, Erin (2004): "Peak placement in Peruvian Spanish". In: Auger, Julia/Clements, J. Clancy/Vance, Barbara (eds.): Contemporary Approaches to Romance Linguistics: Selected papers from the 33rd Linguistic Symposium on Romance Languages (LSRL), Bloomington, Indiana, April 2003. John Benjamins: Amsterdam, pp. 321-341.

Otheguy, Ricardo/Zentella, Ana Celia (2012): Spanish in New York: Language contact, dialect leveling and structural continuity. New York: Oxford.

Pellicer, Dora/Cifuentes, Bárbara/Herrera, Carmen (2006): "Legislating diversity in twenty-first century Mexico". In: Hidalgo, Margarita (ed.): Mexican indigenous languages at the dawn of the Twenty-First century. Berlin: Mouton de Gruyter, pp. 128-166.

Pfeiler, Barbara (1992): “Así som, los de Yucatán: El proceso fonológico $\mathrm{Vn}>\mathrm{m} / \ldots$ _ (\#, C) en dos lenguas en contacto". In: Memorias del Primer Congreso Internacional de Mayistas, vol. 1. San Cristóbal de las Casas, Mexico, pp. 110-122.

PFEILER, Barbara (1993): “Lenguaje e identidad en Yucatán”. In: Unicornio Suplemento Cultural de Por Esto. Merida, Mexico, pp. 3-6.

PfEILER, Barbara,/ZÁMIŠOVÁ, Lenka (2006): "Bilingual education: Strategy for language maintenance or shift of Yucatec Maya?". In: Hidalgo, Margarita (ed.): Mexican indigenous languages at the dawn of the Twenty-First century. Berlin: Mouton de Gruyter, pp. 282-300.

QueZada, Sergio (2001): Breve historia de Yucatán. Mexico City: El Colegio de México.

Rosner, Burton S./LÓPEZ-BASCuAS, Luis E./GARCíA-AlBEA, José E./FAHEY, Richard P. (2000): "Voice-Onset Times for Castilian Spanish Initial Stops". In: Journal of Phonetics, 28, pp. 217-224.

Solomon, Julie (1999): Phonological and syntactic variation in the Spanish of Valladolid, Yucatán. Doctoral Dissertation. Palo Alto, CA: Stanford University.

Solomon, Julie (1996): "Subject expression in Yucatec Spanish: Accounting for similarities and differences in a contact variety". Paper presented at NWAVE-XXV, Las Vegas.

SORACE, Antonella (2004): "Native language attrition and developmental instability at the syntax-discourse interface: Data, interpretations and methods". In: Bilingualism: Language and Cognition, 7, pp. 143-145.

SUÁREZ, Victor. M. (1979): El español que se habla en Yucatán: Apuntamientos filológicos (2nd ed.). Mérida, Mexico: La Universidad de Yucatán.

ThOMAsOn, Sarah. G./KAUfMAn, Terrence (1988): Language contact, creolization and genetic linguistics. Berkley: University of California Press.

TORIBIO, Almeida Jacqueline (2011): “Code-switching among US latinos”. In: Díaz-Campos, Manuel (ed.): The Handbook of Hispanic Sociolinguistics. Wiley-Blackwell: Oxford, pp. 530-552.

TOZZER, Alfred M. (1977): A Maya Grammar. New York: Dover.

WeBER, Irving L. (1980): "Social Organization and Change in Modern Yucatan”. In: Mosely, Edward/Terry, Edward (eds.): Yucatan: A World Apart. University of Alabama: University of Alabama Press, pp. 172-201.

YAGER, Kent (1982): Estudio del cuadro consonántico del español de Mérida, Yucatán con consideraciones de posible influencia maya. University of California: Santa Barbara: Unpublished Master's Thesis.

YAGER, Kent (1989): "La -m bilabial en posición final absoluta en el español hablado en Mérida, Yucatán (México)”. In: Nueva Revista de Filología Hispánica, XXXVII, 1, pp. 83-94. 